\title{
FAKTOR YANG MEMPENGARUHI STRATEGI BERTAHAN HIDUP PEREMPUAN PULAU DI DESA GEDUGAN, PULAU GILIGENTING, KABUPATEN SUMENEP
}

\author{
Ismi Aulil Wardani*, Keppi Sukesi, Reza Safitri \\ Program Pascasarjana, Fakultas Pertanian, Universitas Brawijaya \\ Jl. Veteran, Ketawanggede, Malang \\ *Corresponding author: ismiauli192@gmail.com
}

\begin{abstract}
Income is one of the factors that influence Island women to carry out a survival strategy. Not only that, there are still other factors that influence. These factors are collected in household asset capital, each of which is interrelated and there is also a factor that is most dominating among others. This study aims to identify and analyze the factors that influence the survival strategy in Gedugan Village, Giligenting Island and analyze the relationship between the factors that influence the survival strategy of island women. The method used is quantitative analysis by distributing questionnaires (Likert scale), observation and interviews. The sampling method used was random sampling with Slovin. The variables used in this study are financial capital, social capital, natural capital, physical capital and human capital, while the analytical method used is factor analysis and multiple linear regression analysis. The results showed that the most dominant and most influential factor on the survival strategy of Pulau Perempuan was financial capital.
\end{abstract}

Keywords: island women, survival strategies, livelihood assets

\begin{abstract}
Abstrak: Pendapatan adalah salah satu faktor yang mempengaruhi perempuan Pulau untuk melakukan strategi bertahan hidup. Tidak hanya itu, masih ada faktor lainnya yang mempengaruhi. Faktor-faktor tersebut terkumpul dalam modal aset rumah tangga, dimana masing-masing saling terkait dan ada pula faktor yang paling mendominasi diantara lainnya. Penelitian ini bertujuan untuk mengidentifikasi dan menganalisis faktor-faktor yang mempengaruhi strategi bertahan hidup yang ada di Desa Gedugan Pulau Giligenting dan menganalisis hubungan faktor-faktor yang mempengaruhi dengan strategi bertahan hidup perempuan pulau. Metode yang digunakan adalah analisis kuantitatif dengan menyebarkan kuisioner (skala likert), observasi dan wawancara. Metode pengambilan sampling yang digunakan adalah random sampling dengan slovin. Variabel yang digunakan dalam penelitian ini adalah modal finansial, modal sosial, modal alam, modal fisik dan modal manusia, sedangkan metode analisis yang digunakan adalah analisis faktor dan analisis regresi linear berganda. Hasil penelitian menunjukkan bahwa faktor yang paling mendominasi dan paling berpengaruh tehadap stratei bertahan hidup Perempuan Pulau adalah modal finansial.
\end{abstract}

Kata Kunci: perempuan pulau, strategi bertahan hidup, aset penghidupan

\section{PENDAHULUAN}

Masyarakat nelayan digambarkan dengan ciri rendahnya tingkat kehidupan (low income and low standar of living) masyarakatnya dan hal tersebut sangat nampak pada masyarakat nelayan apabila dilihat dari pola hidup dan ketersediaan papan mereka yang memprihatinkan (Iqbal, 2004). Beberapa hasil penelitian yang lain juga menghasilkan kesimpulan yang tidak berbeda, bahwa standar hidup masyarakat nelayan berada di bawah 
standar hidup yang layak (Kusumo et al., 2013).

Sebagian besar nelayan di Indonesia sudah termasuk dalam extreme poverty, karena pendapatan mereka yang kurang dari US\$ 10 per kapita per bulan. Pendapatan yang tergolong rendah ini tentunya tidak hanya dimiliki oleh laki-laki saja. Akan tetapi juga terjadi pada perempuan pulau yang sumber mata pencahariannya di laut dan akan sangat berdampak pada ekonomi keluarga mereka (Karlita et al., 2017).

Pendapatan nelayan yang rendah, berdampak pada ekonomi keluarga mereka sehingga menyebabkan istri nelayan mencari strategi untuk bertahan hidup. Strategi bertahan hidup ini tidak dilakukan oleh istri nelayan akan tetapi oleh perempuan-perempuan lainnya yang ada di Pulau Giligenting. Lingkungan pesisir memang memiliki peluang kerja yang sedikit karena jumlah lapangan kerja yang masih minim. Kebanyakan lapangan kerja yang ada, hanya seputar tentang pengolahan ikan atau pabrik ikan, bahkan banyak dari perempuan pulau yang menjadi pedagang atau penjual ikan. Sehingga bukan hal tabu lagi jika perempuan pulau khususnya istri nelayan juga berperan dalam meningkatkan ekonomi dalam keluarga nelayan.

Tujuan perempuan pulau yang merupakan istri nelayan melakukan strategi bertahan hidup dengan pola nafkah ganda yaitu untuk memenuhi kebutuhan primer dan sekunder atau peningkatan taraf hidup. Hal tersebut bisa dilakukan dengan menambahkan jenis pekerjaan dan merubah pola mata pencaharian. Strategi bertahan hidup perempuan tidak hanya di sektor ekonomi, tetapi berorientasi pada sektor sosial dan kultural. Pada sektor sosial perempuan melakukan kegiatan gotong royong bersama laki-laki, misal ojek, membangun rumah, jalan raya, mengikuti lembaga kesejahteraan seperti kelompok nelayan, arisan, dan lain-lain. Sedangkan di sektor kultural perempuan bertindak sama seperti laki-laki dalam memenuhi kebutuhan ekonomi (Irwan, 2015).

Menurut Wijayanti (2014), strategi penghidupan selalu menggambarkan tentang bagaimana masyarakat bekerja keras dan berupaya untuk mencapai penghidupan yang memadai serta memanfaatkan kombinasi aset penghidupan yang mereka miliki, mereka juga harus bisa menyikapi dengan lugas setiap sesuatu yang terjadi dan mampu mempertahankan atau memperbaikinya. Ada beberapa pendapat para ahli yang menjelaskan mengenai strategi bertahan hidup. Mosser membuat kerangka analisis yang disebut "The Aset Vulnerability Framework". Kerangka ini meliputi berbagai pengelolaan aset yang dapat digunakan untuk melakukan penyesuaian atau pengembangan strategi dalam mempertahankan kelangsungan hidup, yaitu 1) aset tenaga kerja, 2) aset modal manusia, 3) aset produktif, 4) aset relasi rumah tangga atau keluarga, dan 5) aset modal sosial (Yang et al., 2018).

Lima aset penghidupan rumah tangga menjadi hal yang sangat penting sebagai penunjang strategi bertahan hidup perempuan pulau. Sesuai dengan Muhammad et al. (2014) menjelaskan bahwa ke lima aset rumah tangga yaitu aset tenaga kerja, aset modal manusia, aset produktif, aset keluarga dan aset modal sosial sangat berpengaruh terhadap kehidupan nelayan secara berkelanjutan. Setiap individu dapat memiliki strategi penghidupan yang berbeda tergantung pada aset penghidupan yang tersedia dan beberapa kerentanan yang sedang dihadapi. Laila et al. (2015) dan Sabara (2016) menjelaskan bahwa untuk mengetahui faktor-faktor yang mempengaruhi strategi bertahan hidup perempuan pesisir, maka langkah awal yang harus dikaji adalah aset penghidupan rumah tangga.

Penelitian Widodo (2011), menjelaskan bahwa ada beberapa faktor yang menyebabkan perempuan untuk bekerja mencari nafkah tambahan bagi keluarganya. Faktor-faktor tersebut meliputi faktor sosial, ekonomi dan budaya. Jika dilihat dari beberapa penelitian perempuan pesisir sebelumnya dapat disimpulkan bahwa nelayan bekerja berdasarkan musim, sedangkan perempuan nelayan bekerja sepanjang tahun.

Berdasarkan hasil dari penelitian Laila $e t$ al. (2015), terdapat dua faktor yang mempengaruhi strategi bertahan hidup perempuan nelayan, yaitu faktor internal dan faktor eksternal. Faktor internal terdiri dari karakteristik individu perempuan nelayan yaitu usia, asal etnik, tingkat pendidikan, jenis pekerjaan, pendapatan, etnik dominan keluarga, jumlah anggota rumah tangga dan mata pencaharian utama keluarga, sedangkan faktor eksternal terdiri dari akses terhadap 
sumberdaya modal, hubungan patron-client dan dukungan sosial yang diperoleh perempuan nelayan dalam kehidupan sosialnya. Hal tersebut sedikit berbeda dengan Sabara (2016), yang mana hasil penelitiannya memaparkan bahwa faktor-faktor yang mempengaruhi strategi bertahan hidup perempuan hanya terdiri dari kondisi alam, cuaca, pendapatan dari diversifikasi dan faktor keluarga. Adanya perbedaan faktor dari setiap penelitian yang ada, menjadi salah satu sebab bagi peneliti untuk melakukan penelitian dengan topik yang sama serta untuk mengidentifikasi faktor-faktor yang paling dominan berpengaruh terhadap strategi bertahan hidup.

Pulau Giligenting adalah salah satu pulau yang terdapat di Kabupaten Sumenep dan termasuk dalam wilayah Kecamatan Giligenting. Pada masa sekarang ini keadaan masyarakat Giligenting tersebut banyak yang mengadu nasib ke kota-kota besar guna untuk memenuhi kebutuhan hidupnya dan keluarganya. Menurut salah satu tokoh desa, keadaan tersebut berawal sekitar tahun 1990-an sampai sekarang, proses tersebut menghasilkan banyak perubahan-perubahan khususnya perubahan sosial pada kehidupan masyarakat Giligenting.

Sebuah realita yang memang sudah terjadi di Pulau Giligenting bahwa sebagian besar perempuan pulau yang masih muda bekerja menjadi pedagang di kota-kota besar seperti Jakarta dan lainnya. Namun masih ada sebagian kecil dari mereka yang bertahan hidup dan mencari nafkah di tempat mereka tinggal. Lalu bagaimana cara mereka untuk tetap bisa bertahan hidup diantara perempuan-perempuan lainnya, faktor-faktor apa saja yang mempengaruhi strategi bertahan hidup perempuan pulau dan strategi apa yang mereka lakukan untuk mengimbangi kehidupan dari perempuan-perempuan pulau di sekitarnya yang sudah memiliki pendapatan melebihi dari pendapatan nelayan. Penelitian ini bertujuan untuk mengidentifikasi dan menganalisis faktor-faktor yang mempengaruhi strategi bertahan hidup perempuan pulau di Desa Gedugan, Pulau Giligenting.

\section{METODE PENELITIAN}

Metode yang digunakan pada penelitian ini adalah metode kuantitatif. Dengan populasi penelitian adalah rumah tangga nelayan yang berjumlah 146. Teknik pengambilan sampel yang digunakan adalah random sampling karena jumlah responden yang masih belum diketahui secara pasti. Sedangkan untuk penentuan jumlah sampel peneliti menggunakan rumus slovin, sehingga didapatkan jumlah akhir responden adalah 35 perempuan Pulau yang masuk dalam komunitas nelayan. Data primer didapatkan dari kuisioner yang berlandaskan pada skala likert, wawancara dan observasi, kemudian data yang diperoleh dianalisis melalui dua analisis, yaitu analisis faktor dan regresi linear berganda.

Analisis yang digunakan dalam penelitian bisa diurai seperti dibawah ini:

1. Analisis Faktor

Analisis faktor digunakan untuk mendapatkan hasil faktor yang terbentuk menjadi kelompok yang lebih kecil daripada sebelumnya, dengan masing-masing faktor ke faktor lainnya memiliki hubungan yang kuat atau lemah. Sehingga kemudian setelah didapatkan nilai skor faktor maka akan digunakan untuk uji regresi linear berganda.

\section{Analisis Regresi Linear Berganda}

Analisis ini digunakan untuk mengetahui seberapa besar pengaruh faktor-faktor yang mempengaruhi strategi bertahan hidup, selain itu untuk mengetahui seberapa besar hubungan masing-masing variabel.

\section{Lokasi penelitian}

Penelitian ini dilaksanakan di Desa Gedugan, Pulau Giligenting, Kabupaten sumenep, Jawa Timur. Desa ini merupakan salah satu desa yang terletak di pulau Madura dan merupakan wilayah pesisir yang penduduknya sebagian besar bermata pencaharian sebagai nelayan. Selain itu, di desa ini terdapat usaha perikanan seperti usaha pengolahan ikan dan didekat pantai terdapat pasar ikan sebagai perantara nelayan untuk menjual hasil tangkapannya setiap hari.

\section{HASIL DAN PEMBAHASAN}

Desa Gedugan adalah salah satu desa yang ada di Pulau Giligenting, Kabupaten Sumenep. Di Desa ini terdapat nelayan dengan jumlah terbanyak, sebab itu peneliti memilih untuk melakukan penelitian di daerah ini. Seperti 
pulau-pulau lainnya, pulau ini memiliki sumberdaya perikanan yang melimpah, hanya saja teknologi yang ada masih terbatas. Sehingga aktivitas perikanan yang ada hanya mengalami sedikit perkembangan dari tahun ke tahun.

Para nelayan memiliki pendapatan yang tidak stabil. Hal tersebut membuat perempuan pulau atau istri mereka untuk berperan aktif dalam membantu meningkatkan ekonomi rumah tangga, yaitu salah satunya dengan menjual ikan hasil tangkapan suami mereka dan beberapa pekerjaan lainnya. Perempuan Pulau Giligenting khususnya Desa Gedugan memiliki karakteristik yang sama dengan karakteristik perempuan Madura pada umumnya. Mereka memiliki sifat pemberani, tidak mudah menyerah dan tangguh baik itu dalam hal pekerjaan rumah tangga ataupun membantu suami dalam mencari nafkah. Hampir setiap jenis pekerjaan mereka mau melakukannya yang penting halal dan tidak merugikan sesama. Etos kerja perempuan Madura didorong oleh keyakinan bahwa kerja adalah ibadah, amal dan membentuk kemandirian, berani menghadapi rintangan ibarat berbantal ombak dan berselimut angin.

Pekerjaan atau aktivitas perempuan pulau di Desa Gedugan dimulai dari membantu suami menjual ikan di pasar, mencari kerang, kuli batu, pembuat krupuk, menjaga toko peracangan, menjual gorengan, mencari makan untuk hewan ternaknya dan menjadi petani (jika musim hujan tiba). Bekerja adalah hal yang sudah biasa bagi mereka, selama mereka bisa bertahan hidup atau bisa makan, itu sudah cukup.

Menurut Sudiono (2015), salah satu faktor nelayan melakukan strategi bertahan hidup adalah karena pendapatan yang tidak stabil dan bisa dibilang rendah. Laila et al. (2015), juga mengatakan bahwa faktor ekonomi adalah penyebab terkuat perempuan untuk ikut serta dalam bekerja. Maka sesuai dengan hasil analisis modal finansial memang faktor yang paling dominan dan sangat berpengaruh bagi perempuan pulau di Desa Gedugan dalam melakukan berbagai strategi untuk bertahan hidup.

Tidak hanya modal finansial, akan tetapi modal-modal lainnya seperti modal fisik, modal sosial, modal manusia dan modal alam juga memiliki pengaruh terhadap strategi bertahan hidup perempuan pulau dan saling berkaitan satu sama lainnya, seperti yang sudah dijelaskan pada bab hasil. Jika salah satu modal memiliki nilai rendah, maka sudah tentu akan sangat berpengaruh terhadap strategi bertahan hidup dan juga terhadap modal-modal lainnya.

Keterkaitan antar faktor, bisa sangat melemahkan atau bahkan menguatkan mereka dalam melakukan strategi bertahan hidup. Ada faktor yang mendominasi ada juga faktor yang hanya sedikit berpengaruh. Strategi bertahan hidup menjadi landasan bagi perempuan pulau untuk tetap melangsungkan kehidupannya. Hidup sederhana adalah tujuan mereka, jika mereka memiliki penghasilan lebih itu adalah bonus. Karena jika mereka menginginkan kehidupan dengan perekonomian tinggi maka mereka akan migrasi ke luar kota untuk mencari pekerjaan.

\section{Karakteristik Responden Umur Responden}

Sebagian besar usia produktif yang ada di Pulau Giligenting diatas 30 tahun. Pada usia tersebut mereka banyak melakukan kegiatan khususnya membantu suami dalam meningkatkan perekonomian keluarga mereka. Hal ini sesuai dengan Tabel 1.

Tabel 1. Umur Responden

\begin{tabular}{llcc}
\hline No & Umur & $\begin{array}{c}\text { Fre- } \\
\text { kuensi }\end{array}$ & Persen-tase \\
\hline & & & \\
1 & $18-22$ tahun & 1 & $2,86 \%$ \\
2 & $22-27$ tahun & 1 & $2,86 \%$ \\
3 & $27-32$ tahun & 2 & $5,71 \%$ \\
4 & $>32$ tahun & 31 & $88,57 \%$ \\
\hline Total & & 35 & $100 \%$ \\
\hline
\end{tabular}

(Sumber: Data Primer, 2018)

Dari Tabel 1 dapat disimpulkan bahwa sebanyak $88,57 \%$ perempuan pulau yang bekerja dan masuk dalam kelompok nelayan diatas umur 32 tahun, dikarenakan bagi mereka yang umurnya di bawah 32 tahun memilih untuk merantau atau mencari nafkah di luar pulau Giligenting dan ada sebagian lagi di perguruan tinggi di luar Pulau Giligenting.

\section{Tingkat Pendidikan Responden}

Sebagian dari penduduk Pulau Giligenting mengemban pendidikan di luar Pulau Giligenting, karena sarana pendidikan yang ada terbatas. Sedangkan bagi mereka yang memilih 
sekolah di Pulau Giligenting, hanya sampai pada SD atau SMP saja, setelah itu mereka mulai bekerja dimulai dari membantu ibu untuk menjual ikan ke pasar, mulai ikut melaut bagi yang laki-laki dan ketika berumur 18 tahun, mereka menikah. Dimana setelah menikah, kebanyakan dari mereka bekerja sebagai nelayan bagi yang laki-laki. Selain itu, ada juga yang bermigrasi ke luar kota untuk mencari nafkah karena peluang kerja yang ada sedikit.

Tabel 2. Tingkat Pendidikan Responden

\begin{tabular}{llcc}
\hline No & Pendidikan & Frekuensi & Persentase \\
\hline 1 & Tidak Sekolah & 12 & $34,28 \%$ \\
2 & Tamat SD & 19 & $54,28 \%$ \\
3 & Tamat SMP & 3 & $8,58 \%$ \\
4 & Tamat SMA & 1 & $2,86 \%$ \\
5 & Tamat Universitas & 0 & 0 \\
\hline & Total & 35 & $100 \%$ \\
\hline
\end{tabular}

(Sumber: Data Primer, 2018)

Berdasarkan tingkat pendidikan perempuan pulau yang dijadikan sebagai responden, seperti yang tercantum pada Tabel 2 diatas terlihat bahwa tingkat pendidikan responden terbesar adalah tamat SD atau setara yaitu $54,28 \%$ dan urutan kedua adalah tidak sekolah yaitu sebanyak $34,28 \%$. Hal tersebut terjadi karena pada jaman dulu minimnya sekolah yang ada di pulau tersebut, sampai saat inipun jumlah sekolah yang ada masih minim, khususnya sekolah SMA atau setara. Banyak dari pemuda atau pemudi Giligenting yang memilih untuk mengemban pendidikan di luar pulau, biasanya mereka mondok di pesantren mulai dari SD/MI sampai tamat SMA/MA.

\section{Pekerjaan Responden}

Banyak dari perempuan Pulau yang membantu suami mereka untuk menjual hasil tangkapan ke pasar. Selain itu, mereka juga melakukan pekerjaan darat lainnya untuk membantu meningkatkan perekonomian rumah tangga. Berdasar wawancara, ada beberapa responden yang menganggap bahwa dirinya adalah ibu rumah tangga meskipun telah melakukan diversifikasi pekerjaan, karena bagi mereka pekerjaan yang mereka lakukan tidaklah tetap. Tabel 3 menyajikan pekerjaan responden. Ditinjau dari jenis pekerjaan yang dilakukan perempuan pulau sebagian besar adalah nelayan yaitu sebesar $60 \%$ dan rumah tangga sebesar $31,43 \%$, hal tersebut dikarenakan bahwa meskipun mereka bekerja menjual ikan, dan pekerjaan sampingan lainnya, mereka juga seorang ibu rumah tangga.

Tabel 3. Pekerjaan Responden

\begin{tabular}{llcc}
\hline No & Pekerjaan & Frekuensi & Persentase \\
\hline 1 & Pedagang & 3 & $8,58 \%$ \\
2 & Karyawan & 0 & 0 \\
3 & Ibu Rumah & 11 & $31,43 \%$ \\
& Tangga & & $60 \%$ \\
4 & $\begin{array}{l}\text { Lainnya } \\
\text { (Petani, }\end{array}$ & 21 & \\
& Nelayan, & & \\
& Penjual ikan) & & $100 \%$ \\
\hline \multicolumn{2}{l}{ Total } & 35 & \\
\hline (Sumber: Data Primer, 2018) &
\end{tabular}

(Sumber: Data Primer, 2018)

Perempuan nelayan biasanya bertugas untuk menjemput suami di pantai, dimana mereka akan membawakan hasil tangkapan suami yang kemudian disimpan di lemari es jika jumlahnya sedikit dan akan disimpan di coolbox jika hasil tangkapannya lumayan besar. Hasil tangkapan akan disimpan semalaman dan akan dijual keesokan paginya di pasar.

\section{Pengalaman Kerja Responden}

Sebagian besar perempuan pulau telah bekerja dimulai dari mereka berhenti sekolah, sehingga mereka memiliki pengalaman kerja yang lama. Akan tetapi, pekerjaan yang mereka lakukan adalah dalam bidang perikanan dan beberapa pekerjaan yang ada di Pulau Giligenting seperti memecah batu, mencari kerang, mengangkut batu dan lainnya. Berikut tabel pengalaman kerja yang dimiliki perempuan pulau:

Tabel 4. Pengalaman Kerja Responden

\begin{tabular}{|c|c|c|c|}
\hline No & Pengalaman Kerja & Frekuensi & Persentase \\
\hline 1 & Karyawan & 0 & 0 \\
\hline 2 & Pedagang & 3 & $8,58 \%$ \\
\hline 3 & $\begin{array}{l}\text { Tidak } \\
\text { Bekerja }\end{array}$ & 6 & $17,14 \%$ \\
\hline 4 & $\begin{array}{ll}\text { Lainnya } & \text { (Petani, } \\
\text { Nelayan, } & \text { Penjual } \\
\text { ikan) } & \\
\end{array}$ & 26 & $74,28 \%$ \\
\hline Tot: & & 35 & $100 \%$ \\
\hline
\end{tabular}

(Sumber: Data Primer, 2018)

Salah satu karakteristik responden dalam penelitian ini adalah pengalaman kerja responden, dimana sebesar $74,28 \%$ perempuan pulau memiliki pengalaman dalam menjual ikan. Menjual ikan adalah pekerjaan yang pernah dilakukan setiap perempuan pulau, dan 
bukanlah pekerjaan tetap karena pekerjaan tersebut dilakukan hanya ketika para nelayan melaut dan mendapatkan ikan yang cukup banyak, jika ikan yang dihasilkan sedikit maka ikan tersebut hanya dikonsumsi pribadi saja.

\section{Jenis Keterampilan}

Beberapa keterampilan yang dimiliki perempuan pulau adalah jenis keterampilan yang memang sering dilakukan oleh mereka. Hal ini sesuai dengan kondisi lingkungan dan sumber daya yang ada di Pulau Giligenting khususnya Desa Gedugan. Jenis keterampilan yang dimiliki sebagian besar adalah di bidang perikanan seperti mencari kerang, membantu suami membersihkan kapal dan sebagainya. Tabel 5 menunjukkan jenis keterampilan yang dimiliki oleh responden dalam persen.

Tabel 5. Jenis Keterampilan Responden

\begin{tabular}{clcc}
\hline No & Jenis Keterampilan & Frekuensi & Persentase \\
\hline 1 & Memasak & 5 & 14,28 \\
2 & Menjemur Ikan & 0 & 0 \\
3 & Mencari Kerang & 30 & $85,72 \%$ \\
4 & Lainnya & 0 & 0 \\
\hline & Total & 35 & $100 \%$ \\
\hline
\end{tabular}

(Sumber: data Primer, 2018)

Jenis keterampilan yang terbesar dimiliki perempuan pulau adalah mencari kerang sebesar $85,72 \%$, biasanya para perempuan pulau mulai mencari kerang setiap tanggal 13 sampai 16 setiap bulannya, karena pada tanggal tersebut air laut surut, ketika air laut surut, maka mempermudah bagi perempuan pulau untuk mencari hewan karang seperti kepiting, udang karang, ikan dan khususnya kerang. Untuk melakukan hal tersebut mereka membutuhkan pengalaman dan keterampilan, jika tidak maka hasil yang didapat hanya sedikit dan hanya bisa dikonsumsi sendiri.

\section{Pendapatan}

\section{Pendapatan Suami Responden}

Pendapatan rumah tangga perempuan pulau terdiri dari pendapatan suami dan pendapatan istri dalam melakukan diversifikasi pekerjaan. Perempuan pulau yang menjadi responden diketahui juga memiliki pendapatan dari pekerjaan kecilnya untuk membantu suami mereka, seperti yang ditunjukkan pada Tabel 6 .

Pendapatan suami adalah pendapatan ketika mereka mendapatkan hasil tangkapan atau memancing dalam jumlah yang cukup banyak sehingga bisa dijual ke pasar terdekat bahkan sampai ke luar pulau.

Tabel 6. Pendapatan Suami Respondeni

\begin{tabular}{llcc}
\hline No & Pendapatan & Frekuensi & Persentase \\
\hline 1 & $<350.000$ & 10 & $28,57 \%$ \\
2 & $350.000-$ & 8 & $22,85 \%$ \\
& 450.000 & & \\
3 & $450.000-$ & 10 & $28,57 \%$ \\
4 & 550.000 & & $20 \%$ \\
4 & $>550.000$ & 7 & $100 \%$ \\
\hline \multicolumn{4}{l}{ Total }
\end{tabular}

(Sumber: Data Primer, 2018)

Pendapatan yang dimiliki tidak menentu tergantung kepada hasil tangkapan, akan tetapi menurut para nelayan dan perempuan pulau di Pulau Giligenting Desa Gedugan, rata-rata pendapatan yang dimiliki dibawah Rp.500.000, terkadang tidak setiap hari mereka mendapatkan ikan dan paling banyak mendapatkan ikan adalah pada bulan Desember. Berdasarkan data yang didapatkan dari kuisioner pendapatan paling banyak adalah $<350.000$ sebebesar $28,87 \%$ yang sama jumlahnya dengan rentang pendapatan antara 450.000 - 550.000, sedangkan yang lain mendapatkan jumlah yang tidak jauh berbeda yaitu $350.000-450.000$ sebesar $22,85 \%$ dan untuk pendapatan $>550.000$ sebesar $20 \%$. Hal tersebut dikarenakan hasil tangkapan yang diperoleh oleh para nelayan masin-masing kapal tidaklah sama.

\section{Pendapatan Responden}

Perempuan pulau yang menjadi responden memiliki pekerjaan kecil. Mereka melakukan pekerjaan untuk membantu meningkatkan ekonomi rumah tangga mereka. Berikut adalah tabel pendapatan responden:

Tabel 7. Pendapatan Responden

\begin{tabular}{llcc}
\hline No & Pendapatan & Frekuensi & Persentase \\
\hline 1 & $<350.000$ & 34 & $97,14 \%$ \\
2 & $350.000-$ & 1 & $2,86 \%$ \\
& 450.000 & & \\
3 & $450.000-$ & 0 & 0 \\
4 & 550.000 & & 0 \\
4 & $>550.000$ & 0 & $100 \%$ \\
\hline \multicolumn{4}{l}{ Total }
\end{tabular}

(Sumber: Data Primer, 2018) 
Pendapatan responden adalah jumlah uang yang dihasilkan perempuan pulau dalam bekerja baik dari pekerjaanya di perikanan maupun di luar perikanan, seperti membuat kerupuk, mengumpulkan batu, memukul batu sehinga menjadi bagian kecil untuk bahan dasar meng-aspal jalan. Rata-rata pendapatan yang dimiliki perempuan pulau khususnya istri nelayan yaitu kurang dari Rp.350.000. Pekerjaan utama mereka adalah menjual ikan ke pasar, mencari kerang diwaktu air laut surut, dimana hasilnya nanti akan dijual di pasar.

\section{Perekonomian Masyarakat Pulau Giligenting}

Masyarakat Pulau Giligenting memang terkenal dengan penduduk yang memiliki perekonomian diatas rata-rata, semua berkecukupan karena memang jika dilihat sekilas tidak ada rumah yang kecil, rumah mereka semua kokoh dengan dikelilingi pagar dan berhalaman pasir, asri serta nyaman untuk dipandang. Bagi seseorang yang baru pertama kali berkunjung seperti pariwisatawan maka akan beranggapan bahwa isu tersebut adalah benar. Apalagi, dikatakan bahwa di Pulau tersebut aman dari maling atau pencuri karena tidak ada yang perekonomiannya rendah. Hal tersebut tentu ada yang sebagian dibenarkan oleh Kepala Desa setempat, namun kenyataaanya jika digali lebih dalam lagi tidak semua informasi diatas adalah benar.

Sebagian besar penduduk Giligenting pergi merantau untuk mencari nafkah di luar, tetapi menurut Kepala Desa Gedugan, kebanyakan dari mereka tidak bisa mengelola keuangan dengan baik. Jika mereka memiliki pendapatan tinggi, uangnya habis hanya untuk merenovasi rumah, setelah itu mereka harus kembali ke tempat perantauan untuk meneruskan pekerjaan mereka. Di tempat dimana mereka bekerja, mereka harus mengontrak sebuah rumah untuk tempat tinggal jika itu satu keluarga, menyewa tempat untuk membuka toko dan bertahan untuk biaya hidup sehari-hari. Ada yang juga menyekolahkan anak mereka disana. Jikapun ada yang berhasil memiliki keuntungan besar dalam pekerjaannya, mereka harus tetap bekerja di tempat rantauan dan hanya bisa pulang disaat hari raya tiba (terikat). Rumah yang mereka renovasi mereka tinggalkan tanpa ada yang menempati kecuali mereka masih memiliki tanggungan keluarga seperti orang tua dan anak yang masih sekolah di Pulau tersebut.

\section{Faktor-Faktor yang Mempengaruhi Strategi Bertahan Hidup Perempuan Pulau dengan Analisis Faktor}

Pada tahap selanjutnya, data yang telah terangkum tersebut, dilakukan analisa faktor sebagai analisa untuk mengetahui beberapa faktor yang mempengaruhi strategi bertahan hidup perempuan pulau. Untuk mengetahui tepat tidaknya penggunaan analisis faktor dalam menganalisis data pada penelitian ini, dapat dilihat pada dua hal yaitu dari nilai Barlett Test of Sphericity dan Kaiser-MayerOlkin Measure of Sampling Adequacy. Barlett Test of Sphericity merupakan test statistik yang digunakan untuk menguji hipotesa nol (H0), yaitu semua variabel di dalam populasi tidak berhubungan satu sama lain. Apabila nilai test statistik tersebut tinggi, maka hipotesa nol ditolak. Sebaliknya jika nilai dari test statistik tersebut rendah berarti hipotesa nol tidak gugur, dengan demikian ketepatan penggunaan alat analisis statistik dengan analisis faktor tersebut dipertanyakan (Malhotra, 1993).

Analisis faktor digunakan untuk meringkas atau mereduksi variabel amatan secara keseluruhan menjadi beberapa variabel atau dimensi baru, akan tetapi variabel atau dimensi baru yang terbentuk tetap mampu mempresentasikan variabel utama. Selain itu anaisis faktor juga digunakan untuk mengidentifikasi adanya hubungan antarvariabel penyusun faktor atau dimensi dengan faktor yang terbentuk.

Faktor-faktor yang terbentuk tergabung dalam modal aset rumah tangga yang dimiliki perempuan Pulau. Faktor-faktor yang awalnya dalam jumlah banyak menjadi faktor dengan jumlah lebih sedikit. Semakin sedikit faktor yang terbentuk maka semakin kuat hubungan yang dimiliki oleh masing-masing faktor, karena masing-masing faktor saling mempengaruhi satu sama lain. Faktor ini disesuaikan dengan kondisi aset penghidupan rumah tangga perempuan Pulau yang ada di Desa Gedugan, Pulau Giligenting. Selain itu Faktor-faktor ini juga mengacu pada penelitianpenelitian dasar sebelumnya mengenai strategi bertahan hidup rumah tangga nelayan. 


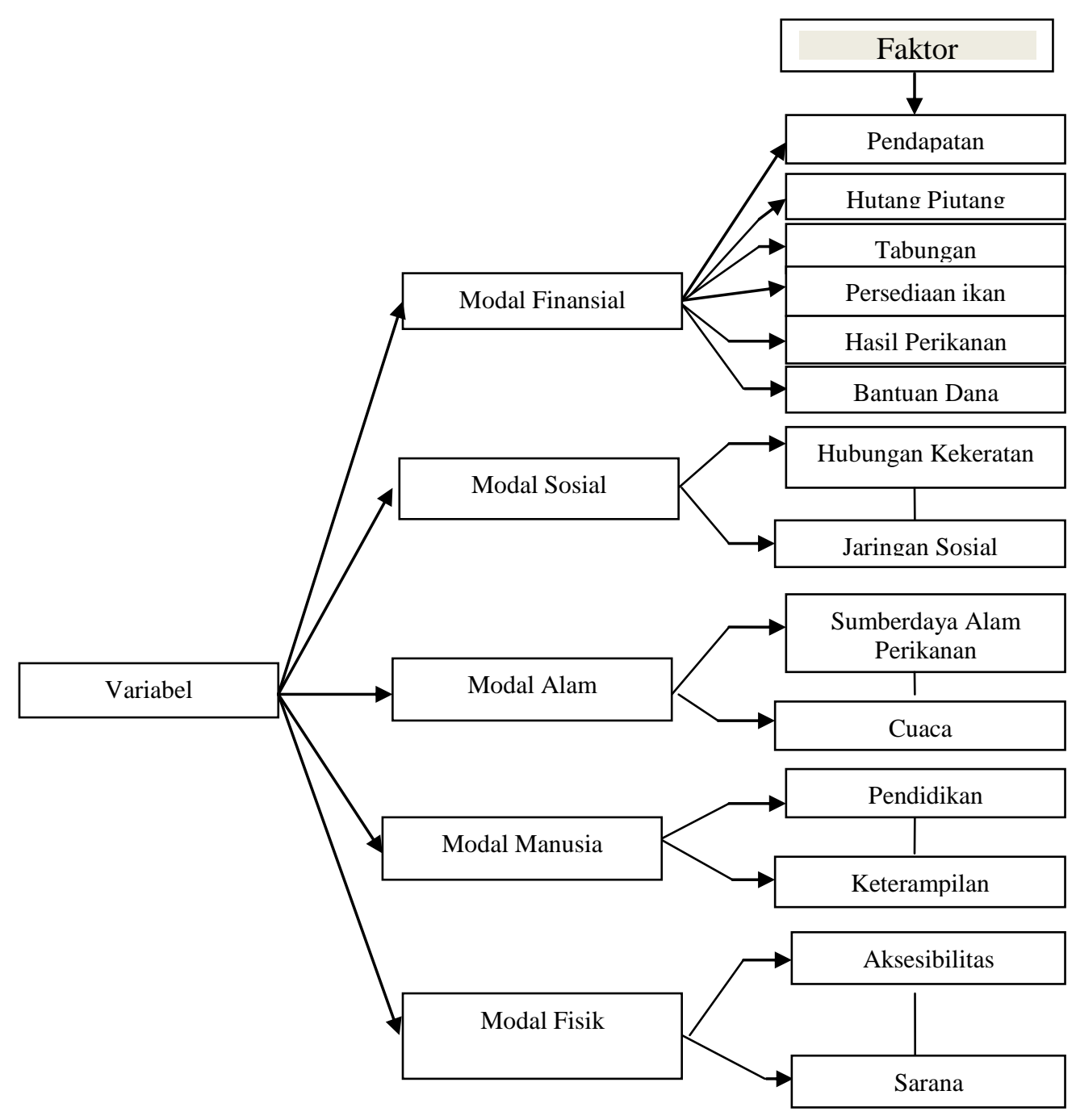

Gambar 1. Variabel Penelitian

Tabel 8. Pengelompokan 5 faktor dalam analisis faktor

\begin{tabular}{lllccc}
\hline & \multicolumn{1}{c}{ Variabel } & $\begin{array}{c}\text { Nilai } \\
\text { Rotasi }\end{array}$ & $\begin{array}{c}\text { Pct.of } \\
\text { variace }\end{array}$ & $\begin{array}{c}\text { Cumulative } \\
\text { Pct. }\end{array}$ \\
\hline Faktor I & $\mathrm{X}_{1}$ & : Pendapatan & 0,921 & 27.847 & 27.847 \\
(Modal & $\mathrm{X}_{2}$ & : Hutang Piutang & 0,886 & & \\
Finansial) & $\mathrm{X}_{3}$ & : Tabungan & 0,819 & & \\
& $\mathrm{X}_{4}$ & : Persediaan ikan & 0,764 & & \\
& $\mathrm{X5}_{5}$ & : Hasil Perikanan & 0,757 & & \\
& $\mathrm{X}_{6}$ & : Bantuan & 0,579 & & 40.298 \\
\hline Faktor II & $\mathrm{X}_{7}$ & : Hubungan Kekerabatan & 0,798 & 12.451 & \\
(Modal Sosial) & $\mathrm{X}_{8}$ & : Jaringan sosial & 0,737 & & \\
\hline Faktor III & $\mathrm{X}_{9}$ & : Sumberdaya Alam Perikanan & 0,828 & 12.401 & 52.700 \\
(Modal Alam) & $\mathrm{X}_{10}$ & : Cuaca & 0,739 & & \\
\hline Faktor IV & $\mathrm{X}_{11}$ & : Pendidikan & 0,801 & 11.402 & 64.101 \\
(Modal anusia) & $\mathrm{X}_{12}$ & : Keterampilan & 0,654 & & \\
\hline Faktor V & $\mathrm{X}_{13}$ & : Aksesibilitas & 0,787 & 9.834 & 73.936 \\
(Modal Fisik) & $\mathrm{X}_{14}$ & : Sarana & & \\
\hline
\end{tabular}

(Sumber: Data Primer, 2018) 
Kelima faktor pada Tabel 8 dapat diinterpretasikan sebagai berikut:

1. Faktor I merupakan kumpulan dari Modal Finansial, yang terdiri dari pendapatan, Hutang Piutang, Tabungan, Hasil Perikanan, Persediaan ikan dan Bantuan dana. Pada Tabel 8 dapat disimpulkan bahwa pada faktor I (Modal Finansal) sekitar 27,847 \%. Pada faktor ini variabel yang memiliki nilai faktor yang paling tinggi atau faktor yang paling dominan berpengaruh adalah pendapatan. Faktor utama yang mengharuskan mereka untuk mencari pekerjaan lain adalah pendapatan. Nelayan tidak selalu memiliki pendapatan yang tinggi, seperti dalam kasus-kasus perikanan sebelumnya, karena tidak setiap hari nelayan mendapatkan hasil tangkapan yang banyak. Akibatnya, istri mereka membuat strategi untuk membantu dalam meningkatkan perekonomian rumah tangga, meskipun tidak banyak pekerjaan yang mereka lakukan. Salah satu pekerjaan yang sangat mudah dijangkau oleh perempuan pulau adalah menjual hasil tangkapan suami. Hal tersebut dilakukan jika hasil tangkapan tidak banyak, karena jika banyak maka nelayan memilih menjual ikan ke pengambak langsung atau menjual ke luar pulau Giligenting. Jika produktivitas perikanan dan persediaan ikan rendah, maka pendapatan yang dimiliki nelayan juga akan rendah, jika keduanya tinggi maka pendapatan nelayan akan tinggi dan peluang mereka untuk menabung akan tinggi. Selain itu jika mereka mendapatkan bantuan dana, maka hal tersebut juga akan berpengaruh terhadap faktor finansial. Misal uang bantuan mereka gunakan untuk membuka usaha dalam bidang perikanan sehingga keuntungan dari usaha tersebut bisa membantu perekonomian rumah tangga nelayan meskipun sedikit demi sedikit.

2. Faktor II adalah modal sosial yang ada di Desa Gedugan, Pulau Giligenting yaitu hubungan kekerabatan dan jaringan sosial. Pada Tabel 8 dapat dilihat bahwa faktor II (Modal Sosial) sekitar 12,451\%. Perempuan pulau memiliki hubungan kekerabatan yang sangat tinggi di Desa Gedugan. Wilayah yang tidak begitu luas justru menjadikan rasa sosial yang ada di Pulau Giligenting sangat tinggi serta Hubungan kekerabatan yang terbentuk menjadi baik. Sulitnya akses transportasi ke luar pulau Giligenting membuat perempuan pulau mau tidak mau harus saling membantu jika ada yang membutuhkan bantuan, sehingga mereka menjadi terbiasa dalam melakukan hal tersebut. Mereka tidak bisa mengandalkan saudara jauh yang rumahnya berada di luar Pulau Giligenting ketika ada sesuatu hal yang mendesak, sebab itu secara perlahanlahan mereka membangun hubungan kekerabatan dan jaringan sosial. Misalnya ketika mereka membutuhkan bantuan tenaga untuk sebuah acara yang sedang berlangsung, maka para tetangga dekat ataupun jauh (masih dalam Pulau) langsung datang untuk membantu.

3. Faktor III adalah modal alam. Pada Tabel 8 dapat dilihat bahwa faktor III (Modal Alam) dapat dijelaskan sekitar 12,401\%. Pulau Giligenting memiliki sumberdaya alam yang melimpah, khususnya sumberdaya perikanan sebab itu banyak penduduk Pulau Giligenting khususnya Desa Gedugan yang bekerja sebagai nelayan. Modal alam yang menjadi variabel adalah sumberdaya alam perikanan dan cuaca. Jika cuaca buruk, seperti hujan atau angin kencang, maka nelayan tidak dapat melaut dan hal tersebut juga bisa membatasi aktivitas dari perempuan pulau. Seperti menjemur kerupuk, mencari kerang, menjual ikan atau aktivitas lainnya yang keluar dari rumah.

4. Faktor IV adalah modal manusia. Modal manusia adalah salah satu faktor yang harus diketahui dalam penelitian ini, yaitu pendidikan dan keterampilan. Pada Tabel 8 dapat dilihat bahwa faktor IV (Modal Manusia) dapat dijelaskan sekitar 11,402\%. Jika variabel pendidikan memiliki nilai rendah maka peluang perempuan pulau untuk memiliki keterampilan lebih semakin sedikit, karena dengan pendidikan seseorang bisa dengan mudah mengasah atau memperbanyak keterampilan yang dimiliki.

5. Faktor $\mathrm{V}$ adalah modal fisik yang terdiri dari aksesibilitas dan sarana. Pada Tabel 8 dapat dilihat bahwa faktor V (Modal Fisik) dapat dijelaskan sekitar 9,834\%. Aksesibilitas dan sarana sangat berpengaruh terhadap strategi bertahan hidup perempuan pulau. Jika sarana yang ada di Desa Gedugan masih belum cukup atau rendah, maka akan 
mengurangi fungsi dari aksesibilitas. Artinya, aksesibilitas yang ada bisa dikatakan tinggi jika semua hal yang menunjangnya sudah terpenuhi. Misal tidak adanya sarana transportastasi yaitu angkutan umum yang dapat membantu perempuan pulau dalam menjual ikan. Sehingga dapat dikatakan bahwa akses jalan perempuan pulau ke tempat kerja masih kurang.

\section{Pengaruh Faktor-Faktor terhadap Strategi Bertahan Hidup Perempuan Pulau dengan Analisis Linear Berganda}

Dalam kaitannya dengan pengujian hipotesis, langkah selanjutnya adalah menganalisis pengaruh ke dua faktor tersebut terhadap Strategi Bertahan Hidup Perempuan Pulau dengan menggunakan analisa regresi. Analisa regresi yang digunakan merupakan analisa regresi linear berganda antara variabel-variabel akses dan karakteristik responden yang telah dihasilkan dari analisa faktor.

Analisis regresi berganda dilakukan untuk mengetahui seberapa besar variabel independen mampu mempengaruhi variabel dependen. Pada analisis regresi berganda dilakukan dengan uji F (uji serempak) dan uji t (uji parsial). Kemudian dari analisis regresi berganda didapatkan hasil sebagai berikut:

Tabel 9. Hasil Analisis Regresi Berganda Setiap Faktor

\begin{tabular}{lclc}
\hline \multicolumn{1}{c}{ Faktor } & $\begin{array}{c}\text { Mdel } \\
\text { Summary } \\
(\mathrm{R} . \\
\text { Square })\end{array}$ & $\begin{array}{c}\text { Anova } \\
\left(\mathrm{F}_{\text {hitung }}>\mathrm{F}_{\text {tabel }}\right)\end{array}$ & $\begin{array}{c}\text { Coeffi } \\
\text { cient } \\
(\beta)\end{array}$ \\
\hline M.Finansial & 0,980 & $231,457>2,45$ & -8.913 \\
M.Sosial & 0,887 & $231,457>2,45$ & $-6,093$ \\
M. Alam & 0,805 & $65,855>2,45$ & $-7,094$ \\
M.Manusia & 0,787 & $59,106>3,32$ & $-2,848$ \\
M. Fisik & 0,936 & $235,010>3,32$ & $-5,453$ \\
\hline
\end{tabular}

Sumber: Data Primer, 2018

Pada analisis regresi linear berganda didapatkan hasil bahwa faktor yang paling berpengaruh secara signifikan terhadap strategi bertahan hidup perempuan pulau adalah modal finansial dengan nilai R.Square 0,980, sedangkan faktor ke-dua adalah Modal Fisik dengan nilai R.Square 0,936.

Penjelasan dari masing-masing faktor dalam modal finansial adalah sebagai berikut:
Untuk variabel pendapatan $\left(\mathrm{X}_{1}\right)$ didapatkan nilai sebesar 0,446, hal ini mengandung arti bahwa setiap kenaikan pendapatan satu satuan maka variabel Strategi Bertahan Hidup (Y) akan naik sebesar 0,446. Jika pendapatan rumah tangga nelayan tinggi, maka hal tersebut akan membantu perempuan pulau dalam melakukan strategi bertahan hidup, misalnya dengan membuka usaha perikanan atau menabung untuk kebutuhan di hari esok.

Variabel Hutang Piutang $\left(\mathrm{X}_{2}\right)$ mendapatkan nilai sebesar 0,477 , maka setiap kenaikan hutang piutang satu satuan akan mempengaruhi variabel $\mathrm{Y}$ sebesar 0,477. Semakin banyak hutang yang dimiliki, maka akan semakin sulit bagi perempuan pulau untuk melakukan strategi bertahan hidup. Misalnya, karena mereka memilki hutang yang tidak kunjung terbayar, maka pendapatan rumah tangga yang didapatkan sebagian ditujukan untuk membayar hutang dan sebagian lagi untuk memenuhi kebutuhan sehari-hari jika itu mencukupi. Sedangkan untuk menjual ikan ke pasar ataupun ke luar Pulau Giligenting masih membutuhkan biaya bensin dan transportasi (ongkos kapal).

Variabel Tabungan $\left(\mathrm{X}_{3}\right)$ mendapatkan nilai sebesar 0,507, maka setiap kenaikan tabungan satu satuan akan mempengaruhi variabel $Y$ sebesar nilai tersebut. Semakin banyak tabungan yang ia miliki, maka akan semakin mudah bagi perempuan pulau untuk melakukan strategi bertahan hidup. Suatu fakta yang terjadi pada perempuan pulau di Desa Gedugan, ketika mereka memiliki tabungan baik itu berupa celengan ataupun dalam bentuk emas (barang berharga), maka ketika mereka mendapatkan masalah seperti tidak dapat membeli kebutuhan pokok atau harus membayar uang sekolah anaknya, maka mereka lebih memilih menjual aset berharga milik mereka atau menggadaikan emas, lalu jika sudah memiliki uang mereka akan menebus kembali emasnya atau bahkan membeli emas kembali sebagai tabungan mereka.

Variabel hasil perikanan $\left(\mathrm{X}_{4}\right)$ mendapatkan nilai sebesar 0,254 , maka setiap kenaikan tabungan satu satuan akan mempengaruhi variabel $\mathrm{Y}$ sebesar nilai tersebut. Produktivitas perikanan sangat berpengaruh terhadap pendapatan nelayan atau perempuan pulau. Jika produktivitas perikanan 
yang ada rendah maka tentu akan sangat berpengaruh terhadap strategi bertahan hidup perempuan pulau. Sumber daya perikanan adalah sumber pendapatan perempuan pulau, jika produktivitas perikanan menurun, maka sulit bagi perempuan pulau untuk mencari pekerjaan lainnya. Artinya bahwa mereka akan sulit untuk melakukan strategi bertahan hidup.

Salah satu penyebeb produktivitas perikanan menurun adalah karena cuaca dan tentunya persediaan ikan pada waktu itu berjumlah sedikit. Persediaan ikan sebagai variabel berikutnya $\left(\mathrm{X}_{5}\right)$ memiliki nilai sebesar 0,691, maka setiap kenaikan satu satuan persediaan ikan akan berpengaruh terhadap variabel $Y$ sebesar nilai tersebut $(0,691)$. Variabel ini sangat berpengaruh terhadap variabel lainnya khususnya variabel dependen, jika persediaan ikan yang didapatkan pada waktu itu rendah atau dalam jumlah sedikit maka strategi bertahan hidup yang dimiliki perempuan pulau juga rendah, karena variabel lainnya juga pasti akan rendah.

Variabel bantuan $\left(\mathrm{X}_{6}\right)$ mendapatkan nilai sebesar 0,554 maka setiap kenaikan variabel bantuan akan berpengaruh terhadap variabel $Y$ sebesar 0,554. Dengan adanya bantuan berupa dana atau perlatan kerja maka akan mempermudah perempuan pulau dalam melakukan strategi bertahan hidup.

\section{KESIMPULAN DAN SARAN}

Kesimpulan dari penelitian strategi bertahan hidup (Live Survival) perempuan Pulau di Desa Gedugan, Pulau Giligenting adalah terdapat lima variabel yang mempengaruhi strategi bertahan hidup, yaitu modal finansial (pendapatan, hutang piutang, tabungan, persediaan ikan, hasil perikanan dan bantuan), Modal sosial (hubungan kekerabatan dan jaringan sosial, modal Alam (sumberdaya alam perikanan dan cuaca), Modal manusia (pendidikan dan keterampilan) dan modal fisik (aksesibilitas dan sarana). Dimana dari kelima faktor diatas terdapat faktor paling dominan mempengaruhi yaitu modal finansial. Kelima variabel tersebut berpengaruh secara siginifikan tehadap strategi bertahan hidup perempuan pulau Desa Gedugan, Pulau Giligenting dengan variabel yang paling berpengaruh yaitu modal finansial dan modal fisik.
Modal finansial dan modal fisik yang dimiliki perempuan pulau di Desa Gedugan masih belum stabil dan termasuk rendah, sehingga mereka perlu melakukan srategi untuk bertahan hidup.

\section{DAFTAR PUSTAKA}

Kusumo, R.A.B, Charina, A., Mukti, G.M. 2013. Analisis Gender dalam Kehidupan Keluarga nelayan di Kecamatan Pangandaran Kabupaten Ciamis. Journal Social Economic of Agriculture, 2 (1), 42-53.

Iqbal, M. 2004. Strategi Nafkah Rumah Tangga Nelayan (Studi Kasus di Dua Desa Nelayan Tangkap Kabupaten Lamongan Jawa Timur). Tesis. Institut Pertanian Bogor. Bogor.

Irwan. 2015. Strategi Bertahan Hidup Perempuan Penjual Buah-Buahan. Jurnal Humanus, 14 (2), 183-195.

Karlita dan Pandjaitan. 2017. Strategi Bertahan Hidup Perempuan di Daerah Pesisir. Jurnal Sains Kominikasi Dan Pengembangan Masyarakat, 1(3), 287298.

Malhotra, N.K. 1993. Marketing Research: An Applied Orientation. London: Prentice Hall.

Muhammad, S., Islamy, I., dan Sukoharsono, E. G. 2014. Pemberdayaan Heptagon (tujuh) Akses Rumah Tangga Masyarakat Miskin. Malang: UB Press.

Laila, N., Evi, N. dan Amanah, S. 2015. Strategi Nafkah Perempuan Nelayan terhadap Pendapatan Keluarga. Jurnal Sosiologi Pedesaan, 1(1), 159-168.

Sabara, M.R. 2016. Strategi Bertahan Hidup (Life Survival) Petani Garam di Desa Tanoh Anoe Kecamatan Jangka Kabupaten Bireuen. Jurnal Ilmiah Mahasiswa Pertanian Unsyiah, 1 (1), 353-368.

Sudiyono. 2015. Strategi Bertahan Hidup Nelayan P.Rimau Balak di Kabupaten Lampung Selatan. Jurnal Bina Praja, 7(3), 211-226. 
Ismi A. W., Keppi S., Reza S.: Faktor yang Mempengaruhi Strategi ...

Widodo, S. 2011. Strategi Nafkah Berkelanjutan Bagi Rumah Tangga Miskin di Daerah Pesisir. Jurnal Makara Sosial Humaniora, 15 (1), 10-20.

Wijayanti, R. 2016. Strategi Penghidupan Berkelanjutan Masyarakat Berbasis Aset di Sub DAS Pusur, DAS Bengawan
Solo. Jurnal Wilayah dan Lingkungan, 4(2), 133-152.

Yang, L., Liu, M., Lun, F., Min, Q., Zhang, C., dan Li, H. 2018. Livelihood Assets and Strategies among Rural Households. Comparative Analysis of Rice and Dryland Terrace System in China. Sustainability, 10 (2525), 1-18. 